\title{
ASSESSMENT OF THE QUALITY AND IRRIGATION PURPOSE SUITABILITY OF ALLUVIAL WATER IN ERFOUD, MOROCCO
}

\author{
Beata Latos ${ }^{1}{ }^{1,2}$, Anna SzczucińsKa ${ }^{1}{ }^{1}$, RafaŁ KozŁowski ${ }^{3}{ }^{3}$ \\ ${ }^{1}$ Institute of Physical Geography and Environmental Planning, Adam Mickiewicz University in Poznań, Poland \\ ${ }^{2}$ Institute of Geophysics, Polish Academy of Sciences, Warsaw, Poland \\ ${ }^{3}$ Department of Environmental Protection and Modelling, Jan Kochanowski University in Kielce, Poland
}

Manuscript received: January 13, 2019

Revised version: July 30, 2019

Latos B., SzczucińsKa A., KozŁowsKi R. 2019. Assessment of the quality and irrigation purpose suitability of alluvial water in Erfoud, Morocco. Quaestiones Geographicae 38(3), Bogucki Wydawnictwo Naukowe, Poznań, pp. 67-79. 4 figs, 6 tables.

AвSTRACт: Dry areas are especially exposed to the risk of water shortages and elevated mineralization. High water salinity, caused by low precipitation, high evaporation and human impact, usually strongly limits the use of the water for irrigation. The aim of the study was to assess the quality and irrigation purpose suitability of alluvial water in the Erfoud oasis, Morocco. The samples of water were collected from 20 wells in June 2017. We observed excessive concentrations of many parameters i.a.: $\mathrm{NO}_{3^{\prime}} \mathrm{Cd}, \mathrm{Ni}, \mathrm{Na}, \mathrm{NH}_{4^{\prime}} \mathrm{Cl}, \mathrm{SO}_{4^{\prime}} \mathrm{Fe}, \mathrm{Cr}$. To determine the possibility to use the water for irrigation purposes, the Sodium Adsorption Ratio (SAR), sodium percentage (\%Na), permeability index (PI), Kelly's ratio (KR), magnesium hazards $(\mathrm{MH})$ and electrical conductivity (EC) were assessed. The values of KR and MH qualified the waters as unsuitable for irrigation purposes. The observed $\% \mathrm{Na}$ indicates that the groundwater is permissible for irrigation purposes, and permeability index, that it is of moderate quality. However, water classification using the SAR vs EC diagram confirms its high and very high alkali and salinity hazard. The mean EC value of the water was $9.5 \mathrm{mS} \mathrm{cm}^{-1}$.

KEY WORDS: water quality, groundwater chemistry, salinity, SAR, Morocco

Corresponding author: Beata Latos, latos.bee@gmail.com

\section{Introduction}

Access to a sufficient amount of good quality water has always been of key importance for the functioning of mankind. In the 21st century, it is still of primary importance. Global water resources are very diverse in terms of their amount, availability and quality. It depends on many factors, i.a., climate zone, anthropogenic environmental pressure, biological productivity, and mineralization. In the dry zone, the availability of freshwater is usually very limited, and surface water and shallow groundwater are characterized with high salinity (El Mandour et al. 2008, Ammar et al. 2016, Fakharian, Narany 2016). In hot, dry areas, the high content of mineral salts in water is related to low precipitation and intensive evaporation.

The amount of water used for agricultural, animal breeding and industrial purposes has increased recently. Salinity of groundwater in Morocco has been investigated many times (i.a., Bahaj et al. 2013, Bouchaou et al. 2008, El Mandour et al. 2008, Dłużewski et al. 2017). Elevated concentration of sodium and its negative influence on the ecosystem have been pointed out. Salt makes it difficult for plants to absorb nutrients and has a 
negative impact on the metabolism of organisms living in the soil, reducing its fertility. High salinity of soil makes plants die out due to the increase of osmotic pressure and due to salt toxicity. Another important aspect occurring in saline soils is oxygen depletion (Dłużewski et al. 2017). It is assumed that for waters used for irrigation purposes, electrical conductivity (EC) should be between 600 and $1700 \mu \mathrm{cm}^{-1}$ (Wilcox 1955). However, in many areas of hot and dry climate zone, the values are higher, which considerably limits their irrigation usability. Examples of that are studies carried out in Australia (Williams 2001), India (Deshpande, Ather 2012) and Tunisia (Alaya et al. 2014). But because of the lack of other sources of water suitable for irrigation, excessively saline water is still used in Erfoud, which only adds to the problem. In many cases, the proportion of chemical compounds and elements exceeds the World Health Organization (WHO) standards for drinking water quality (WHO 2017). This occurs i.a., in the case of nitrates $\left(\mathrm{NO}_{3}\right)$, iron $(\mathrm{Fe})$, sulfates $\left(\mathrm{SO}_{4}\right)$, chlorine $(\mathrm{Cl})$ or already mentioned sodium $(\mathrm{Na})$. The dominant type of groundwater, com-

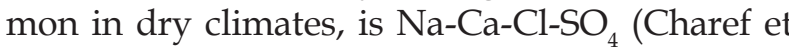
al. 2009, Hamzaoui-Azaza et al. 2011, Lachaal et al. 2013, Alaya et al. 2016).

Sensitive oasis ecosystems, struggling with the problems of availability of water resources and human impact, have recently been affected by extremely strong factors that even threaten their existence. Important steps in sustainable approach to the development of oases were the construction of dams, the creation of a new irrigation system (unlike traditional khettaras), and adjusting the means of environmental protection to their natural resources. Despite these efforts, at the end of the $20^{\text {th }}$ century, the oases of Morocco were regarded to be in a critical situation, and now they are in a state of dangerous struggle for survival (Mainguet et al. 2011). The global boom in groundwater irrigation in the world's more arid areas is observed. $38 \%$ of the total cultivated land under irrigation is equipped by water wells (Foster, Garduño 2013). Currently, the oasis areas are subject to excessive exploitation (uncontrolled pumping out) of alluvial groundwater. This is the result of irrigation of fields, using water from wells, the surface water of the Ziz River and water from the Al Hassan Addakhil Dam reservoir, located approx. $70 \mathrm{~km}$ north of Erfoud.
Agricultural production is mostly based on the cultivation of date palm trees. Irrigation is usually performed with methods that contribute to water loss, whereas drip irrigation system is applied in very few places.

The aim of our study was to assess the quality and irrigation purpose suitability of alluvial water in hot and dry zone, illustrated with the example of Erfoud oasis in Morocco, where the majority of irrigation users depend on water wells. Dry areas are very sensitive ecosystems. Therefore, it is extremely significant to monitor the quality and irrigation suitability of alluvial water, which is an important economic aspect of life of local residents.

\section{Study area}

The Erfoud oasis is located in eastern Morocco, in the Er Rachidia region, behind the Atlas Mountains.

The Erfoud oasis is located in a flat upland area, mildly sloping southwards at the height of approx. 800 meters above sea level (Fig. 1 A, B), where aridisols occur. An important role in soil formation processes is also played by clay cracks, eolian processes and vegetation that tends to grow in tufts. As a result of evaporation, the products of weathering of minerals and rocks are raised to the soil profile ceiling, where layers of accumulated alkaline (calcium and sodium) salts also visible as crusting. Three geographical geology-based sub-basins in the Ziz basin were found: the Jurassic limestone of High Atlas Mountains extending from the southern flank of the Mountains to the major South Atlas Fault in the piedmont; Cretaceous and Cenozoic formations from the South Atlas fault to Jbel Erfoud and Paleozoic formations outcropping to the southern part of the studied basin. Erfoud oasis is located within Limestone, Schists, and Sandstone of Carboniferous, with some alluvial deposits of Quaternary (Lgourna et al. 2014).

The oasis is located in the area of tropical, hot and very dry climate with the mean annual precipitation of 50 to $200 \mathrm{~mm}$. January and February are the driest months, and precipitation is the highest in October, November and September. July is the warmest month. The mean annual temperature is approx. $20^{\circ} \mathrm{C}$, with amplitudes up 


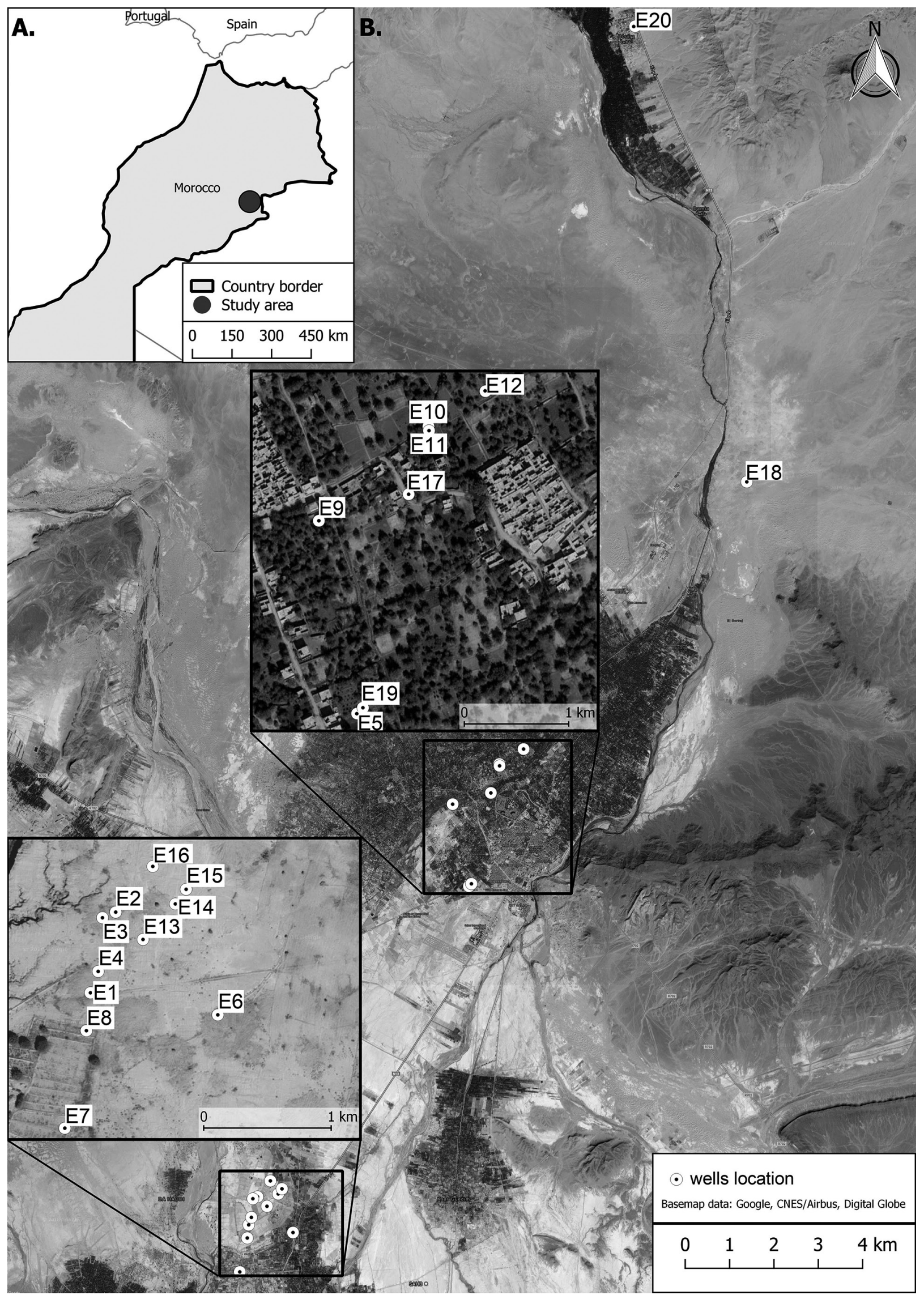

Fig. 1. The location of the study area against Morocco (A) together with location of the wells in Erfoud (B). 
to $50^{\circ} \mathrm{C}$ (El Khoumsi et al. 2014). Evaporation is considerably higher than precipitation, reaching up to $4000 \mathrm{~mm} \mathrm{yr}^{-1}$.

Rainfall and snowfall in the Atlas Mountains are the main source of water for the periodic river Ziz, which flows across Erfoud. Current climate changes have far-reaching consequences for the river regime, visible i.a., in the speed of flow, the levels of water accumulation, as well as relationships between ecosystems (Whitehead et al. 2009). Apart from climate changes, water management also affects the local water conditions. People have built dams on the Ziz River, which retain water in the reservoirs and create wetlands, thus changing the environmental conditions. Al Hassan Addakhil Errachidia Dam is the nearest dam. The area of the watershed is 4400 $\mathrm{km}^{2}$, with reservoir capacity of $347 \mathrm{Mm}^{3}$ (Akdi, Sedra 2015). The purpose of the dam is to regulate the wadi in order to carry out the Ziz valley and Tafilalet lands agricultural development, as well as to provide flood protection.

More and more private pumps are used within the study area, which additionally aggravates the growing tendency to lower the groundwater level. Prolonged droughts contribute to low groundwater level, and the local residents extensively use alluvial waters. Approximately 25000 people live in the oasis, with the highest population density in the city centre, along the river and the canals. The groundwater is used for domestic, agricultural and municipal purposes. The water treatment is rare. Thus, the groundwater can be contaminated with sewage.

Natural vegetation in the river valley has been destroyed in many places. There are scarce pomegranate trees and fig trees. The main plant is date palm, which is able to develop even when watered with highly saline water (over $10 \mathrm{~g} \mathrm{dm}^{-3}$ ). Apart from date palm trees, bur clover, various cereals and vegetables are commonly cultivated.

An important element of water management is canals, diverting water from the Ziz River to nearby fields. Their construction is open, which allows water to evaporate. Arable fields are mostly irrigated with the traditional method, i.e., periodically poured with water. Very few farmers have the drip irrigation system. However, as the access to water is getting more difficult and the awareness of ecological problems is increasing, the number of fields irrigated this way is currently growing.

\section{Methods}

\section{Fieldwork}

The fieldwork was carried out in June 2017, just before opening of water gates in the Al Hassan Addakhil Errachidia Dam, during the end of the dry season. According to irregular flow in the Ziz River, there is no seasonal variation (in regular intervals) of the characteristics of groundwater. Episodic changes due to the periodic flooding of the area is present. Nevertheless, it is hard to capture because of lack of a public information of opening of the dam and water flow in the river. During field studies 20 wells were investigated: 18 dug wells, reaching groundwaters (between 1 and $10 \mathrm{~m}$ deep) and 2 drilled wells, reaching waters located $30 \mathrm{~m}$ (E12) and $20 \mathrm{~m}$ (E17) deep. The investigated wells were selected due to the different depths of the water table and the diversified electrical conductivity. The field studies involved the basic measurement of physico-chemical parameters of groundwater, such as temperature (T) and specific electrical conductivity (EC). Both $\mathrm{T}$ and EC were measured with a conductivity meter (CC-401, Elmetron), with automatic compensation to the reference temperature of $25^{\circ} \mathrm{C}$ and the accuracy of $\pm 1 \%$ and $\pm 1^{\circ} \mathrm{C}$, respectively. Samples of water from all investigated wells were taken for further laboratory analyses, collected in tight-capped polyethylene bottles and transported in cold storage.

\section{Physico-chemical analyses of groundwater}

Before each analysis, the samples were filtered through a glass microfiber filter Whatman GF/D. The analysis of chemical composition (the main anions and cations) was carried out using a ion chromatograph (DIONEX ICS 3000) with analytical columns: IonPac CS16 $3 \times 250 \mathrm{~mm}$ (for cations) and IonPac AS18 $2 \times 250 \mathrm{~mm}$ (for anions). The levels of detection for the studied parameters were: for $\mathrm{Ca}, 0.4 \mathrm{mg} \mathrm{dm}^{-3}$, and for other ions, 0.1 $\mathrm{mg} \mathrm{dm}{ }^{-3}$. The calibration curve was plotted based on Dionex six cation II standard and Dionex seven anion standard II. Heavy metals (Al, As, Cd, Co, $\mathrm{Cr}, \mathrm{Cu}, \mathrm{Fe}, \mathrm{Mn}, \mathrm{Ni}, \mathrm{Pb}$ and $\mathrm{Zn}$ ) were analyzed using an ICP MS TOF spectrometer (Optimass 9500 GBC). The calibration curve was plotted based on certified reference material (CLMS 2AN). All 
Table 1. Measured and expected concentration values of selected elements in certified reference materials.

\begin{tabular}{|c|c|c|c|c|c|}
\hline \multirow{3}{*}{ Analyte } & \multicolumn{2}{|c|}{ ERM-CA713 } & \multicolumn{2}{|c|}{ ICP MS TOF } & \multirow{2}{*}{ Dev. ** } \\
\hline & Concentration & \pm Uncertainty & Concentration & $\pm S D^{*}$ & \\
\hline & \multicolumn{4}{|c|}{$\left[\mu \mathrm{g} \mathrm{dm}^{-3}\right]$} & [\%] \\
\hline $\mathrm{Mn}$ & 95.0 & 4.0 & 91.0 & 1.2 & -4.2 \\
\hline $\mathrm{Fe}$ & 445.0 & 27.0 & 450.0 & 0.6 & 1.1 \\
\hline $\mathrm{Cu}$ & 101.0 & 7.0 & 97.0 & 2.1 & -3.9 \\
\hline $\mathrm{Cd}$ & 5.09 & 0.2 & 4.9 & 2.3 & -3.7 \\
\hline $\mathrm{Pb}$ & 49.7 & 1.7 & 48.1 & 1.1 & -3.2 \\
\hline $\mathrm{Zn}$ & 78.0 & - & 73.0 & 1.4 & -6.4 \\
\hline $\mathrm{Cr}$ & 20.9 & 1.3 & 22.0 & 3.1 & -5.0 \\
\hline $\mathrm{Ni}$ & 50.3 & 1.4 & 48.8 & 2.8 & -3.1 \\
\hline \multirow{3}{*}{ Analyte } & \multicolumn{2}{|c|}{ KEIJM-02 } & \multicolumn{2}{|c|}{ ICS 3000} & \multirow{2}{*}{ Dev. ** } \\
\hline & Concentration & \pm Uncertainty & Concentration & $\pm S D$ * & \\
\hline & \multicolumn{4}{|c|}{$\left[\mathrm{mg} \mathrm{dm}^{-3}\right]$} & {$[\%]$} \\
\hline $\mathrm{Ca}$ & 0.852 & 0.085 & 0.824 & 1.3 & -3.2 \\
\hline $\mathrm{Mg}$ & 0.467 & 0.038 & 0.450 & 1.2 & -3.6 \\
\hline $\mathrm{K}$ & 0.224 & 0.032 & 0.230 & 1.4 & 2.6 \\
\hline $\mathrm{Na}$ & 3.800 & 0.321 & 3.880 & 1.0 & 2.2 \\
\hline $\mathrm{Cl}$ & 5.790 & 0.411 & 5.620 & 0.7 & -2.9 \\
\hline $\mathrm{SO}_{4}$ & 2.420 & 0.038 & 2.350 & 2.0 & -2.8 \\
\hline
\end{tabular}

* - standard deviation.

** - relative difference between the measured and certified concentrations $100 \%\left(c_{\mathrm{z}}-c_{\mathrm{c}}\right) / c_{\mathrm{c}}$.

the solutions were prepared using $1 \%$ nitritic acid Suprapur. The following solutions were prepared for calibration: 0 (blank), 1, 10, 50, 100 and 1000

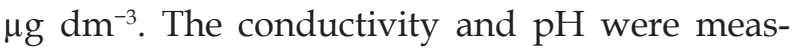
ured with a multi-parameter water quality meter (Hach HQ 40d), whose electrodes were calibrated before each measurement series with Hamilton standards with $\mathrm{pH} 4,7$ and 9 and conductivity 15 $\mu \mathrm{S} \mathrm{m} \mathrm{m}^{-1}$.

Certified reference material KEIJM-02 from Environment Canada and ERM-CA713 from Institute for Reference Materials and Measurements, Belgium, were used for the purpose of quality control of the obtained results. The obtained values of concentration of the analyzed elements are presented in Table 1.

\section{Statistical analyses}

The water quality of each sample was plotted on a classical Piper diagram, referring to the concentrations (meq $\mathrm{dm}^{-3}$ ) of hydrochemical components (Piper 1944). This diagram provides a convenient method to classify and compare water types based on the ionic composition of different water samples (Hem 1985). To assess the usability of the waters for irrigation the following ratios were used: sodium total percentage $(\% \mathrm{Na})$ (Wilcox 1955), permeability index (PI) (Ragunath
1987), magnesium hazard (MH) (Szabolcs, Darab 1964), Kelly's ratio (KR) (Kelly 1963), and sodium adsorption ratio (SAR) (Richards 1954). The type of ion exchange was deduced from the base exchange index (BEI), given by the following formula: $\mathrm{BEI}=([\mathrm{Cl}]-[\mathrm{Na}+\mathrm{K}]) /[\mathrm{Cl}]\left(\mathrm{meq} \mathrm{dm}^{-3}\right)$. BEI $<0$ indicates the fixation of $\mathrm{Ca}$ and $\mathrm{Mg}$ and solubilization of $\mathrm{Na}$ and $\mathrm{K}$. BEI $>0$ indicates the fixation of $\mathrm{Na}$ and $\mathrm{K}$ and solubilization of $\mathrm{Ca}$ and $\mathrm{Mg}$.

\section{Results and Discussion}

\section{Water chemical composition}

The adequacy of groundwater for agricultural and domestic uses is directly related to the different physiochemical parameters and their concentrations. Table 2 presents detailed characteristics of the wells from which water was sampled for chemical composition analyses. The water table lies at the height of 742 to $867 \mathrm{~m}$ a.s.l. The height of the water column differs from well to well and ranges from below $1 \mathrm{~m}$ to approx. 10 $\mathrm{m}$. The mean temperature of water is $22^{\circ} \mathrm{C}$ (from minimum $18.3^{\circ} \mathrm{C}$ to maximum $24.4^{\circ} \mathrm{C}$ ). The study wells are recharge with alluvial water, which is often found in the area of Morocco. Wells of this type of supply are also found in other regions, 
Table 2. Geographical coordinates and basic characteristics of the wells in Erfoud.

\begin{tabular}{|c|c|c|c|c|c|c|}
\hline Well ID & $\begin{array}{c}\text { Coordinates } \\
\mathrm{N}\end{array}$ & $\begin{array}{c}\text { Coordinates } \\
\text { E }\end{array}$ & $\begin{array}{l}\text { Altitude } \\
{[\mathrm{m} \text { a.s.1.] }}\end{array}$ & $\begin{array}{l}\text { Depth to the water table } \\
{[\mathrm{m}]}\end{array}$ & $\begin{array}{l}\text { Water column } \\
{[\mathrm{m}]}\end{array}$ & $\begin{array}{c}\text { Water temperature } \\
{\left[{ }^{\circ} \mathrm{C}\right]}\end{array}$ \\
\hline E1 & $31^{\circ} 21^{\prime} 39.6^{\prime \prime}$ & $4^{\circ} 17^{\prime} 53.6^{\prime \prime}$ & 759 & 13.5 & 1.0 & 22.3 \\
\hline E2 & $31^{\circ} 22^{\prime} 00.2^{\prime \prime}$ & $4^{\circ} 17^{\prime} 46.1^{\prime \prime}$ & 764 & 13.5 & 1.0 & 23.9 \\
\hline E3 & $31^{\circ} 21^{\prime} 58.6^{\prime \prime}$ & $4^{\circ} 17^{\prime} 50.3^{\prime \prime}$ & 783 & 13.5 & $<1.0$ & 21.9 \\
\hline E4 & $31^{\circ} 21^{\prime} 45.0^{\prime \prime}$ & $4^{\circ} 17^{\prime} 51.3^{\prime \prime}$ & 781 & 13.7 & $<1.0$ & 24.4 \\
\hline E5 & $31^{\circ} 25^{\prime} 46.0^{\prime \prime}$ & $4^{\circ} 14^{\prime} 45.7^{\prime \prime}$ & 758 & 15.6 & 9.0 & 22.2 \\
\hline E6 & $31^{\circ} 21^{\prime} 34.0^{\prime \prime}$ & $4^{\circ} 17^{\prime} 15.8^{\prime \prime}$ & 760 & 15.6 & $<1.0$ & 20.9 \\
\hline E7 & $31^{\circ} 21^{\prime} 56.3^{\prime \prime}$ & $4^{\circ} 18^{\prime} 01.2^{\prime \prime}$ & 759 & 14.4 & 2.0 & 22.7 \\
\hline E8 & $31^{\circ} 21^{\prime} 30.0^{\prime \prime}$ & $4^{\circ} 17^{\prime} 54.8^{\prime \prime}$ & 756 & 14.2 & 1.5 & 23.4 \\
\hline E9 & $31^{\circ} 26^{\prime} 45.7^{\prime \prime}$ & $4^{\circ} 14^{\prime} 59.6^{\prime \prime}$ & 809 & 3.8 & 4.0 & 18.3 \\
\hline E10 & $31^{\circ} 27^{\prime} 14.9^{\prime \prime}$ & $4^{\circ} 14^{\prime} 19.8^{\prime \prime}$ & 821 & 7.4 & 3.0 & 20.5 \\
\hline E11 & $31^{\circ} 27^{\prime} 43.6^{\prime \prime}$ & $4^{\circ} 14^{\prime} 19.6^{\prime \prime}$ & 820 & 6.8 & 5.0 & 20.1 \\
\hline E12 & $31^{\circ} 27^{\prime} 25.8^{\prime \prime}$ & $4^{\circ} 13^{\prime} 59.1^{\prime \prime}$ & 820 & 7.4 & $<1.0$ & 20.5 \\
\hline E13 & $31^{\circ} 21^{\prime} 53.1^{\prime \prime}$ & $4^{\circ} 17^{\prime} 38.0^{\prime \prime}$ & 767 & 13.4 & $<1.0$ & 22.1 \\
\hline E14 & $31^{\circ} 22^{\prime} 02.1^{\prime \prime}$ & $4^{\circ} 13^{\prime} 59.1^{\prime \prime}$ & 773 & 14.0 & 2.5 & 22.5 \\
\hline E15 & $31^{\circ} 22^{\prime} 05.8^{\prime \prime}$ & $4^{\circ} 17^{\prime} 25.2^{\prime \prime}$ & 772 & 14.2 & 3.0 & 21.8 \\
\hline E16 & $31^{\circ} 22^{\prime} 11.6^{\prime \prime}$ & $4^{\circ} 13^{\prime} 59.1^{\prime \prime}$ & 779 & 14.2 & $<1.0$ & 23.2 \\
\hline E17 & $31^{\circ} 26^{\prime} 53.9^{\prime \prime}$ & $4^{\circ} 14^{\prime} 27.0^{\prime \prime}$ & 817 & 3.4 & 10.0 & 20.4 \\
\hline E18* & $31^{\circ} 30^{\prime} 40.1^{\prime \prime}$ & $4^{\circ} 10^{\prime} 48.7^{\prime \prime}$ & 851 & 1.4 & 7.0 & 21.5 \\
\hline E19 & $31^{\circ} 25^{\prime} 47.8^{\prime \prime}$ & $4^{\circ} 14^{\prime} 43.6^{\prime \prime}$ & 836 & 8.0 & 10.4 & 23.2 \\
\hline E20* & 3136'11.1" & $4^{\circ} 12^{\prime} 24.0^{\prime \prime}$ & 878 & 10.7 & 1.4 & 24.0 \\
\hline
\end{tabular}

* Wells located farthest northward, out of the Erfoud oasis.

for example, oued Draa river (Warner et al. 2013), oued Tassaout River (Rochdane et al. 2015), oued Souss and Massa rivers (Bouchaou et al. 2008). Alluvial waters in Erfoud are characterized by a similar chemical composition as alluvial waters of other regions.

Statistical characteristics of the tested waters are presented in Table 3. The water had neutral or weakly alkaline reaction. Specific EC of the studied waters ranged from 3900 to 15800 $\mu \mathrm{S} \mathrm{cm}{ }^{-1}$ ), which shows that the waters are saline. The main cations and anions display very similar spatial variation. Regarding spatial variation of selected water parameters in the Erfoud oasis, the highest sodium cation concentrations were observed in wells no. E11 and E12 in the northern part of Erfoud oasis and in wells no. E4, E8 and E15 in the southern part. In the case of sulphate anions, the highest values were also observed in wells no. E11 and E12 and in wells no. E4, E8, E13 and E15. The lowest concentrations of the main ions were found in well no. E17. This well is a complex one, both dug (around $10 \mathrm{~m}$ ) and drilled (another $10 \mathrm{~m}$ ), and is often used to water crops.

High salinity of waters, which are used for domestic and agricultural purposes, is a big problem in the arid and semi-arid zone of Morocco. The occurrence in groundwater of high salinity values is described in many regions in Morocco (Laftouhi et al. 2003, El Bakouri et al. 2008, Fakir et al. 2001) and also in other places (Batista et al. 2002, Cerejeira et al. 2003, Morvan et al. 2006, Baran et al. 2007, Hildenbrandt et al. 2008, Andrade, Stigter 2009). This salinity is associated with natural and anthropogenic contaminant. The natural factor is primarily the presence of evaporates (halite, gypsum) in the geological structure, which contain easily dissolved salts. In addition to the lithological nature of the reservoir, the intensive irrigation may contribute to an enhanced salinity.

The concentrations of trace elements and nitrogen forms (nitrates and the ammonium ion) display a mosaic character. There is a possibility that the content of nitrogen, as well as some heavy metals, is associated with anthropogenic pollution due to the lack of proper water treatment system. In the case of nitrates, a concentration higher than the World Health Organization standard for drinking water (WHO 2017) was only exceeded in well no. E11 and was 59.3 $\mathrm{mg} \mathrm{dm}{ }^{-3}$. However, higher concentration, 155 $\mathrm{mg} \mathrm{dm}{ }^{-3}$, was observed in well no. E20, which is located out of Erfoud and is not included in the above spatial distribution (Fig. 1, Tab. 3). As shown by Lgourna et al. (2014), based on the two 


\begin{tabular}{|c|c|c|c|c|c|c|c|c|c|c|c|c|c|c|c|c|c|c|c|c|c|c|c|c|}
\hline$\tau$ & $\overline{8}$ & $\overline{8}$ & $\bar{z}$ & $\begin{array}{l}\hat{\mathrm{j}} \\
\stackrel{n}{ }\end{array}$ & $\overline{0}$ & $\overline{8}$ & tr. & $\overline{8}$ & $\overline{8}$ & $\overline{8}$ & $\overline{0}$ & $\begin{array}{l}n \\
\infty \\
0 \\
0\end{array}$ & $\overline{8}$ & $\overline{0}$ & $\bar{\nabla}$ & $\overline{8}$ & Lִ & 0 & $\overline{8}$ & $\overline{7}$ & $\begin{array}{l}10 \\
\infty \\
\infty \\
0\end{array}$ & $\overline{0}$ & $\overrightarrow{\text { ते }}$ & $\overrightarrow{\tilde{D}}$ \\
\hline & $\begin{array}{l}\overrightarrow{0} \\
\infty \\
\vec{m} \\
\end{array}$ & $\begin{array}{l}8 \\
\text { o } \\
\text { के }\end{array}$ & $\begin{array}{l}\infty \\
\text { హิ } \\
\text { के }\end{array}$ & $\begin{array}{l}\underset{Z}{\mathbb{Z}} \\
\text { n }\end{array}$ & 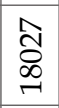 & 於 & $\begin{array}{l}0 \\
\stackrel{0}{0} \\
\infty \\
\infty\end{array}$ & กิ & హ్ & \begin{tabular}{|c|} 
\\
$\stackrel{2}{\circ}$ \\
$\stackrel{2}{二}$ \\
\end{tabular} & 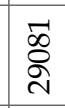 & $\begin{array}{l}\infty \\
\stackrel{\infty}{0} \\
\stackrel{2}{\sigma} \\
\end{array}$ & $\begin{array}{l}\vec{D} \\
\ddot{D} \\
\text { D }\end{array}$ & 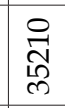 & $\begin{array}{l}m \\
\sigma \\
\alpha \\
\infty \\
\infty\end{array}$ & 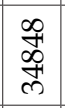 & $\begin{array}{l}0 \\
\infty \\
\infty\end{array}$ & $\begin{array}{l}\hat{A} \\
\text { î̀ }\end{array}$ & 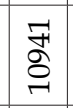 & Iี & $\begin{array}{l}m \\
\sigma \\
\sigma \\
m \\
m\end{array}$ & $\stackrel{\infty}{\infty}$ & 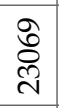 & 尽 \\
\hline & ஜ & I & 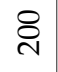 & Б゙ & $\stackrel{\widetilde{I}}{\stackrel{1}{*}}$ & $\hat{\sigma}$ & $\vec{d}$ & $\stackrel{+}{\infty}$ & กิ & a & $\stackrel{L}{\llcorner}$ & F & Fi & $\overline{8}$ & 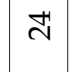 & 8 & 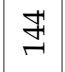 & ले & $\stackrel{ }{\circ}$ & $\stackrel{\infty}{+}$ & $\vec{\sim}$ & $\overline{0}$ & $\stackrel{\infty}{\stackrel{\bullet}{二}}$ & $\widehat{\delta}$ \\
\hline & 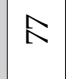 & ถి & $\vec{m}$ & 7 & $\stackrel{10}{\sim}$ & $\begin{array}{l}\infty \\
\infty\end{array}$ & F & है & హ゙ & $\bar{\nabla}$ & $\bar{\nabla}$ & $\overline{7}$ & $\overline{8}$ & $\overline{7}$ & $\overline{8}$ & $m$ & $\bar{z}$ & $\widehat{6}$ & $\vec{N}$ & 8 & హ゙ & $\overline{7}$ & in & స̃ \\
\hline T: & ?ై & $\begin{array}{c}\hat{\Lambda} \\
\text { o. } \\
+\end{array}$ & $\begin{array}{l}\stackrel{1}{\mathrm{~N}} \\
\mathrm{~N} \\
\mathrm{~L}\end{array}$ & $\widehat{\alpha}$ & ง & $\overline{8}$ & $\begin{array}{l}0 \\
\stackrel{0}{\circ}\end{array}$ & $\overline{8}$ & $\underset{\sim}{\stackrel{\sim}{+}}$ & $\overline{0}$ & $\bar{\nabla}$ & ले & $\overline{8}$ & $\overline{8}$ & $\overline{8}$ & $\overline{8}$ & 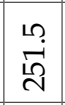 & $\begin{array}{l}0 \\
\stackrel{2}{N}\end{array}$ & $\widehat{\curvearrowright}$ & $\overline{8}$ & 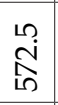 & $\bar{z}$ & 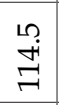 & $\stackrel{+}{\stackrel{+}{\sim}}$ \\
\hline$\stackrel{60}{=}$ & $\stackrel{\llcorner}{R}$ & $\stackrel{F}{+}$ & $\vec{d}$ & $\stackrel{\circ}{\dot{q}}$ & $\stackrel{\circ}{\stackrel{\text { रे }}{ }}$ & $\stackrel{g}{\rightrightarrows}$ & Nִ & 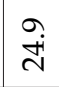 & $\hat{\sigma}$ & $\overline{0}$ & $\begin{array}{l}0 \\
\stackrel{0}{\sim} \\
\stackrel{n}{n}\end{array}$ & $\overline{8}$ & $\overline{8}$ & $\overline{0}$ & $\overline{0}$ & กี & $\begin{array}{l}+ \\
\dot{D} \\
\infty\end{array}$ & $\hat{\sigma}$ & $\begin{array}{l}0 \\
\stackrel{\sim}{\sim}\end{array}$ & 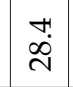 & $\stackrel{2}{R}$ & $\overrightarrow{8}$ & $\begin{array}{l}0 \\
\dot{D} \\
\stackrel{d}{0}\end{array}$ & $\stackrel{\infty}{\stackrel{\infty}{\sim}}$ \\
\hline & 犬ิ & ฟู & 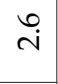 & $\bar{z}$ & $\stackrel{10}{\wedge}$ & $\stackrel{m}{\infty}$ & $\stackrel{\stackrel{n}{\mathrm{~N}}}{\mathrm{~N}}$ & $\underset{+}{\sigma}$ & $\stackrel{\curvearrowright}{\sim}$ & $\overline{8}$ & $\overline{0}$ & $\overline{0}$ & $\overline{8}$ & $\overline{0}$ & $\overline{8}$ & $\overline{8}$ & $\overline{8}$ & $\stackrel{L}{\mathrm{~N}}$ & $\stackrel{m}{+}$ & सु & $\hat{\mathrm{I}}$ & $\overline{0}$ & $\underset{+}{\sigma}$ & $\ddot{\infty}$ \\
\hline & స్ & 18 & $\ddot{N}$ & $\begin{array}{l}\stackrel{\sigma}{0} \\
\hat{n}\end{array}$ & 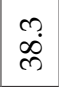 & $\begin{array}{l}\wedge \\
\infty \\
\text { ஸे }\end{array}$ & $\begin{array}{l}n \\
\stackrel{2}{0} \\
10\end{array}$ & $\begin{array}{l}0 \\
\stackrel{1}{1} \\
\text { ल }\end{array}$ & $\underset{\infty}{-1}$ & $\begin{array}{c}0 \\
\stackrel{0}{+} \\
\stackrel{+}{+}\end{array}$ & 命 & 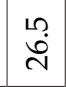 & 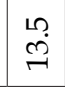 & $\ddot{H}$ & $\ddot{0}$ & $\stackrel{\infty}{\stackrel{\infty}{F}}$ & $\overline{8}$ & $\begin{array}{l}m \\
\dot{i}\end{array}$ & 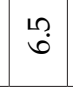 & $\stackrel{\circ}{\stackrel{+}{\sim}}$ & $\begin{array}{c}\overrightarrow{1} \\
\infty \\
\infty\end{array}$ & $F$ & 吕 & 롱 \\
\hline & $\overline{8}$ & $\stackrel{\rightleftarrows}{\rightleftarrows}$ & $\overline{8}$ & $\circ$ & 7 & $\overline{8}$ & $\overline{8}$ & $\overline{8}$ & $\stackrel{\infty}{+}$ & $\overline{8}$ & $\overline{8}$ & $\overline{8}$ & $\overline{8}$ & $\overline{8}$ & $\overline{8}$ & $\overline{8}$ & $\overline{8}$ & $\stackrel{a}{\infty}$ & $\stackrel{\wedge}{\vec{\sigma}}$ & 7 & $\stackrel{\wedge}{\vec{\sim}}$ & $\overline{0}$ & $\stackrel{\circ}{\circ}$ & $\stackrel{n}{\infty}$ \\
\hline & चี & $\bar{z}$ & $\bar{z}$ & $\overline{8}$ & $\overline{0}$ & $\overline{8}$ & $\overline{8}$ & 7 & $\overline{8}$ & $\overline{8}$ & $\overline{8}$ & $\overline{8}$ & $\overline{8}$ & $\overline{7}$ & $\overline{8}$ & $\overline{8}$ & $\overline{8}$ & $\overline{8}$ & $\stackrel{0}{\rightarrow}$ & $\overline{8}$ & $\stackrel{0}{-}$ & $\overline{8}$ & 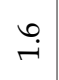 & 1 \\
\hline & $\stackrel{\circ}{i}$ & $\overline{0}$ & ก̃. & $\stackrel{m}{0}$ & $\stackrel{\ddot{m}}{\oplus}$ & $\stackrel{m}{i}$ & $\stackrel{\stackrel{2}{0}}{0}$ & $\stackrel{\circ}{r}$ & 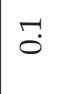 & $\stackrel{\infty}{\circ}$ & $\begin{array}{c}m \\
\ddot{n} \\
\ddot{n}\end{array}$ & $\tilde{c}$ & $\stackrel{\circ}{r}$ & $\stackrel{M}{D}$ & $\bar{g}$ & $\stackrel{m}{\mathrm{i}}$ & 文 & $\stackrel{m}{\rightarrow}$ & \begin{tabular}{|l|}
$\infty$ \\
$\stackrel{\infty}{\infty}$ \\
\end{tabular} & 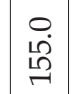 & $\begin{array}{l}\circ \\
\stackrel{0}{0} \\
\text { مी } \\
\sim\end{array}$ & $\overline{8}$ & $\begin{array}{l}\stackrel{1}{\longrightarrow} \\
\stackrel{\leftrightarrow}{\longrightarrow}\end{array}$ & 穴 \\
\hline
\end{tabular}

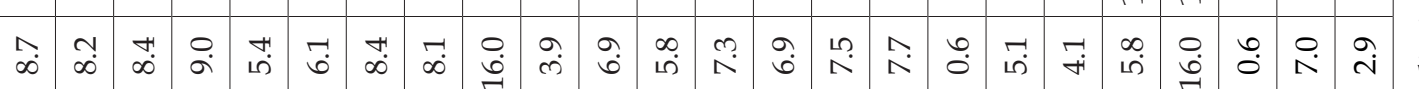

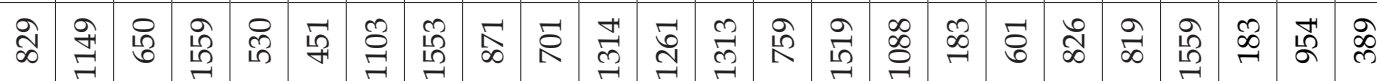

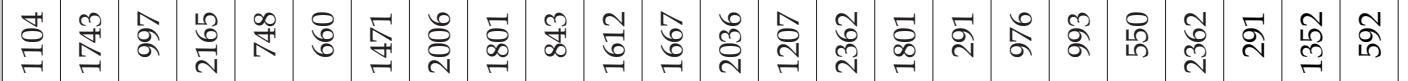

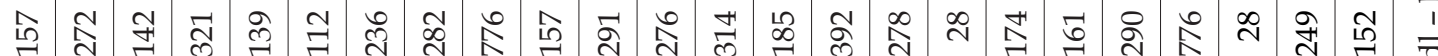
न

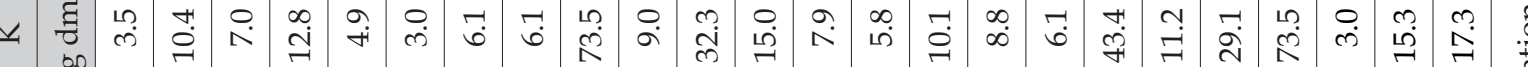
ह

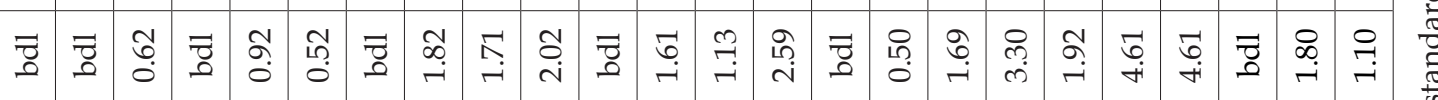
央点

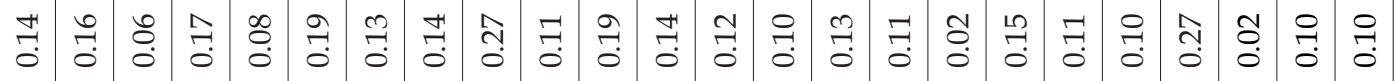

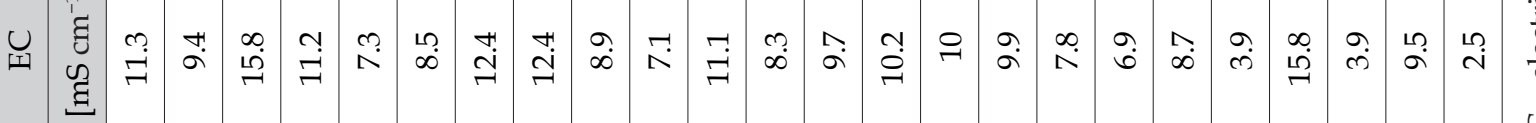

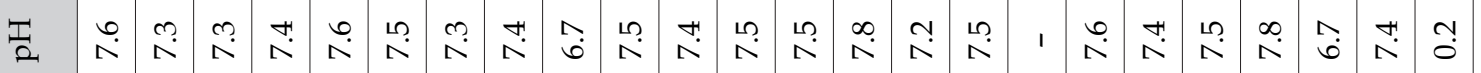


field campaigns carried out during May 2009 and April-May 2010, concentrations of nitrates in the area of the Ziz basin ranged from 0 to 316 $\mathrm{mg} \mathrm{dm}{ }^{-3}$; in total $25 \%$ of wells exceed the recommended limit of $50 \mathrm{mg} \mathrm{dm}^{-3}$. This may imply anthropogenic contamination derived from local agriculture.

The major ions in this study area were plotted in the Piper diagram (Piper 1944) to identify the different types of the groundwater and understand their relation. Based on the tested samples we found that two hydrochemical types of water dominate in the study area: $\mathrm{Na}-\mathrm{Cl}-\mathrm{HCO}_{3}-$ $\mathrm{SO}_{4}$ and $\mathrm{Na}-\mathrm{Cl}-\mathrm{Mg}-\mathrm{SO}_{4}$; there are also waters with multiple ions: $\mathrm{Na}-\mathrm{Mg}-\mathrm{Cl}-\mathrm{SO}_{4}-\mathrm{HCO}_{3}$ (Fig. 2). The dominant type of groundwater, common in dry climates, not only in Morocco but also i.a., in Tunisia, is Na-Ca-Cl-SO ${ }_{4}$ (Charef et al. 2009, Hamzaoui-Azaza et al. 2011, Lachaal et al. 2013, Alaya et al. 2016).

To assess the type of ion exchange, the base exchange index (BEI) was used. The BEI index (Tab. 4) shows the following types of ion exchange in groundwater: $\mathrm{Na}$ and $\mathrm{K}$ are replaced by $\mathrm{Ca}$ and $\mathrm{Mg}$ in $65 \%$ the samples (BEI $>0$ ), while $\mathrm{Ca}$ and $\mathrm{Mg}$ are replaced with $\mathrm{Na}$ and $\mathrm{K}$ in 35\% samples $(\mathrm{BEI}<0)$.
Table 4. Base exchange index (BEI) of water in the tested wells.

\begin{tabular}{|l|r|c|r|}
\hline \multicolumn{1}{|c|}{ Well ID } & BEI & ID sample & BEI \\
\hline E1 & -0.10 & E11 & -0.04 \\
\hline E2 & 0.04 & E12 & 0.02 \\
\hline E3 & -0.06 & E13 & 0.15 \\
\hline E4 & 0.00 & E14 & 0.19 \\
\hline E5 & -0.01 & E15 & 0.17 \\
\hline E6 & 0.00 & E16 & 0.21 \\
\hline E7 & 0.05 & E17 & 0.10 \\
\hline E8 & 0.04 & E18 & -0.06 \\
\hline E9 & 0.31 & E19 & -0.09 \\
\hline E10 & -0.05 & E20 & 0.02 \\
\hline
\end{tabular}

An increase in sodium and chlorides with the increase of water salinity was found. The correlation coefficient, however, was 0.46 , lower than in areas located south of Erfoud, where it reaches 0.90 (Warner et al. 2013). This may be connected with other processes, which determine the hydrochemical type of the water. The diagrams of $\mathrm{Na} / \mathrm{Cl}$ versus $\mathrm{Cl}$ (Fig. $3 \mathrm{~A}$ ) and $\mathrm{Ca}+\mathrm{Mg}$ versus $\mathrm{Cl}$ (Fig. 3 B) clearly show that salinity increases with the decrease in $\mathrm{Na} / \mathrm{Cl}$ and increase in $\mathrm{Ca}+\mathrm{Mg}$, which may be due to reverse ion exchange in the weathered layer (Appelo, Postma 1994). The figure $3 \mathrm{~B}$ shows two outliers. The reason for their dissimilarity is more likely that the well no. 20

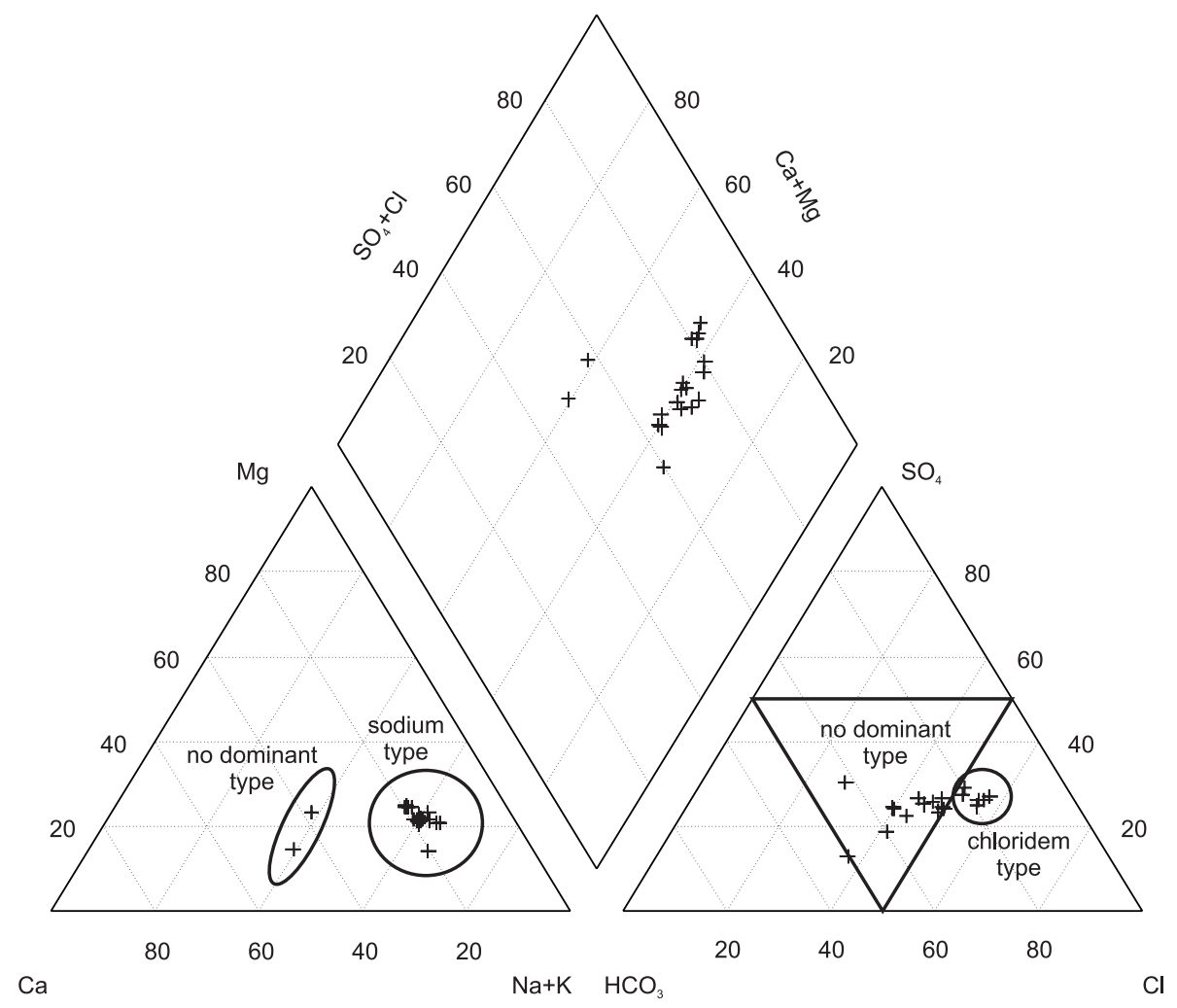

Fig. 2. Piper Diagram indicating the hydrochemical type of water. 
is located a few $\mathrm{km}$ north than the other ones, and the temperature of water in the well no. 9 is the lowest $\left(18.3^{\circ} \mathrm{C}\right.$, whereas others temperatures reach more than $20^{\circ} \mathrm{C}$ ).

In alluvial waters of the oasis, a high correlation was found between salinity and sulfate concentrations (Fig. 3 C), for which $r=0.84$. The high ratio suggests that the source of sulfates may be the dissolution of evaporites, such as gypsum, which can also be confirmed by the correlation between sulfates and strontium, for which $r=$ 0.41 .

The location of the sites along the line of $\mathrm{SO}_{4}+\mathrm{HCO}_{3}$ versus $\mathrm{Ca}+\mathrm{Mg}$ may also suggest the dissolution of gypsum, as well as calcite and
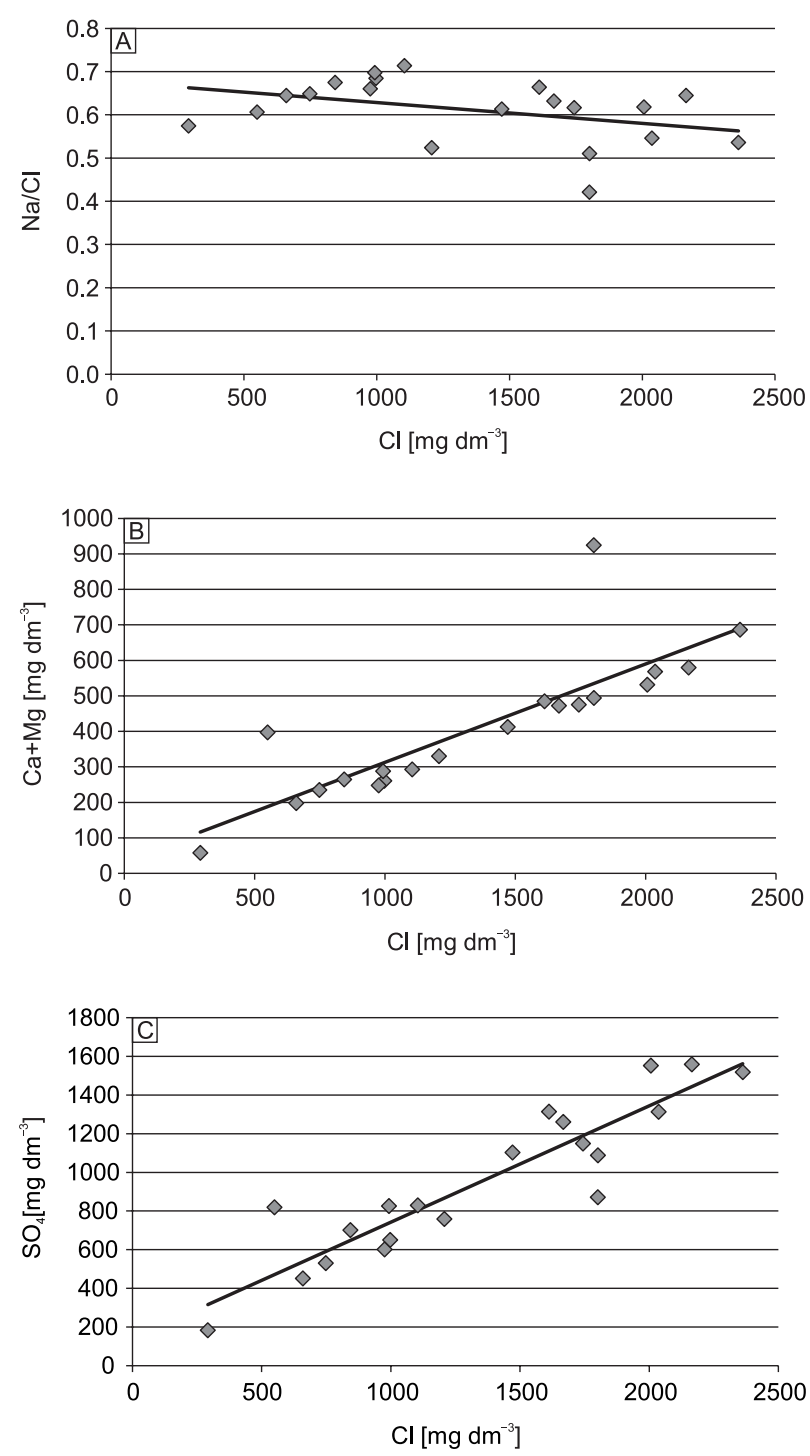

Fig. 3. Relationships $\mathrm{Na} / \mathrm{Cl}$ versus $\mathrm{Cl}$ concentrations $\left(\mathrm{mg} \mathrm{dm}^{-3}\right)(\mathrm{A}), \mathrm{Ca}+\mathrm{Mg}$ versus $\mathrm{Cl}$ concentrations $\left(\mathrm{mg} \mathrm{dm}^{-3}\right)(\mathrm{B})$ and $\mathrm{Cl}$ versus $\mathrm{SO} 4$ concentrations $\left(\mathrm{mg} \mathrm{dm}^{-3}\right)(\mathrm{C})$ for water samples from the study area. dolomite rock. This could explain the hydrochemical type of the water, in which the dominant cations are the sodium ion and the magnesium ion. The molar ratio of $\mathrm{Na} / \mathrm{Cl}$ is in general $<1$, indicating a possible recent recharge due to direct rain water infiltration. The second explanation refers to the salt concentration in the investigated wells. Since it increases above the norm, more sodium is taken onto the soil cation exchange sites, thus lowering the sodium to chloride ratio (Kirchner et al. 2001). This pattern of behavior is consistent with ion exchange buffering of sodium in the catchment soils.

\section{Assessment of alluvial water for irrigation purpose}

In the study area, agricultural activity is quite intensive. Hence, an attempt is also made to understand the suitability of groundwater for agriculture purposes. Table 5 presents the values of water salinity indicators. The total sodium percentage $(\% \mathrm{Na})$ was between 40 and 66, Kelly's ratio between 0.6 and 1.9 , the magnesium hazard between 24 and 64, and permeability index between 44 and 72 .

Table 5. Indicators for evaluating the irrigation suitability of groundwater from the regions of Erfoud.

\begin{tabular}{|l|c|c|c|c|}
\hline $\begin{array}{c}\text { Well } \\
\text { ID }\end{array}$ & $\begin{array}{c}\text { Total } \\
\text { sodium } \\
\text { percentage } \\
\text { \%Na }\end{array}$ & $\begin{array}{c}\text { Kelly's } \\
\text { ratio }\end{array}$ & $\begin{array}{c}\text { Magnesium } \\
\text { hazard }\end{array}$ & $\begin{array}{c}\text { Permeability } \\
\text { index }\end{array}$ \\
\hline E1 & 64 & 1.80 & 59 & PI [-] \\
\hline E2 & 61 & 1.54 & 55 & 68 \\
\hline E3 & 64 & 1.76 & 58 & 64 \\
\hline E4 & 62 & 1.63 & 57 & 64 \\
\hline E5 & 59 & 1.42 & 53 & 64 \\
\hline E6 & 59 & 1.46 & 56 & 64 \\
\hline E7 & 60 & 1.49 & 55 & 64 \\
\hline E8 & 61 & 1.56 & 59 & 64 \\
\hline E9 & 41 & 0.65 & 24 & 44 \\
\hline E10 & 60 & 1.48 & 53 & 65 \\
\hline E11 & 61 & 1.53 & 52 & 65 \\
\hline E12 & 61 & 1.53 & 54 & 64 \\
\hline E13 & 57 & 1.32 & 57 & 60 \\
\hline E14 & 57 & 1.30 & 56 & 60 \\
\hline E15 & 56 & 1.26 & 55 & 58 \\
\hline E16 & 56 & 1.26 & 56 & 59 \\
\hline E17 & 66 & 1.89 & 64 & - \\
\hline E18 & 66 & 1.90 & 41 & 72 \\
\hline E19 & 62 & 1.63 & 56 & 67 \\
\hline E20 & 40 & 0.62 & 38 & 45 \\
\hline
\end{tabular}


Based on the values of KR and MH coefficients, the water was classified as unsuitable for irrigation purposes (in $90 \%$ and $85 \%$, respectively). $\% \mathrm{Na}$ indicates that the groundwater is permissible. Sodium concentration plays an important role in evaluating the groundwater quality for irrigation, because sodium causes an increase in the hardness of soil as well as a reduction in its permeability (Arumugam, Elangovan 2009, Jalali 2009). Based in the permeability index, the water is classified as moderate quality for agricultural purposes.

Sodium concentration is important when evaluating the suitability of groundwater for irrigation. The values of Sodium Adsorption Ratio (SAR) calculated for the Erfoud area are within the range of 4.2 to 14.1. In order to identify the availability of waters for irrigation, the Wilcox classification diagram was used. Water classification with the SAR vs EC diagram confirms the high and very high alkali and salinity hazard (Fig. 4).

The samples are located in field C4, indicating high salinity hazard. Regarding alkali hazard, $21 \%$ of the water is at risk of medium, $42 \%$ of high, and $31 \%$ of very high sodium hazard. The location in the C4-S4 area (31\% samples) shows that this water is saline and cannot be used on soil with restricted drainage. Even with adequate drainage, special management for salinity control may be required, and plants with good salt tolerance should be selected. In C4-S3 classes ( $42 \%$ samples), salinity is medium and classified as brackish water. The water can be used if a moderate amount of leaching occurs. Plants with moderate salt tolerance can be grown.

The results of hydrochemistry, supported by statistical analysis, suggest mainly the natural contaminants in groundwater of this area. EC, $\mathrm{Na}, \mathrm{Cl}$ appeared as major chemical quality issues in groundwater of this area. The nutrient load in groundwater was comparatively low as compared to a load of cation and anion concentration. However, locally over-normative concentrations of trace elements and nutrients are observed. These are likely due to locally anthropogenic effects, which explain their spatial variability.

\section{Health-based guidance level by WHO}

The United Nations (UN) General Assembly declared in 2010 that safe and clean drinking water and sanitation is a human right. The adoption of the Sustainable Development Goals in 2015 by many countries, including Morocco, involves targets and indicators of safe drinking water. Table 6 presents the parameters, which exceeded the health-based guidance level for drinking water determined by the WHO (2017).

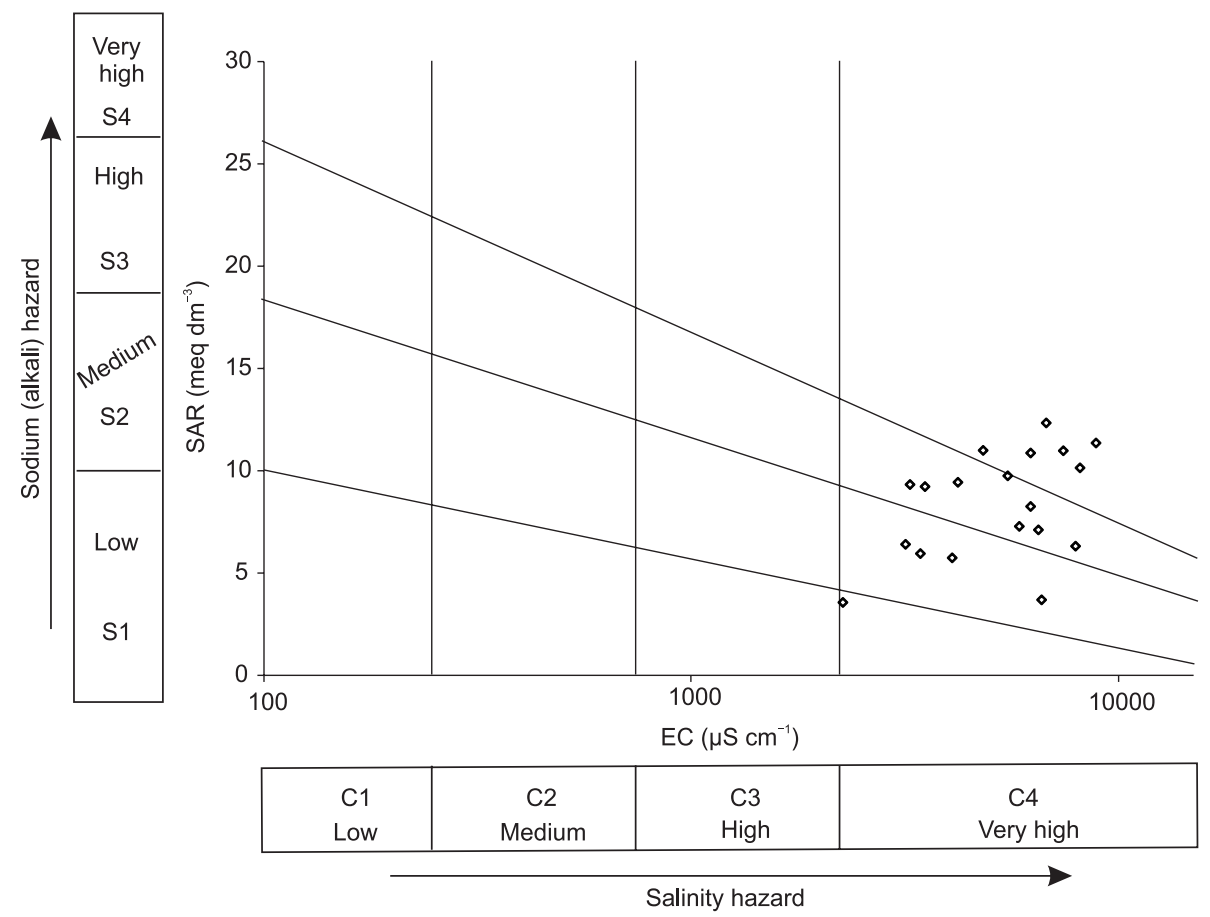

Fig. 4. Parameters SAR and EC classified together on the Wilcox's diagram. 
Table 6. Parameters exceeding the WHO health-based guidance level (2017).

\begin{tabular}{|c|c|c|}
\hline Parameter & Health-based guidance level & Comment \\
\hline $\mathrm{NO}_{3}$ & $50 \mathrm{mg} \mathrm{dm}^{-3}$ & $\begin{array}{l}\text { The parameter was exceeded in the case of two wells: in well } \\
\text { no. E11 the value was } 59 \mathrm{mg} \mathrm{dm}^{-3} \text {, and in well no. E20, even } 155 \\
\mathrm{mg} \mathrm{\textrm {dm } ^ { - 3 }} \text {. This is very dangerous, since water from well no. E20 is } \\
\text { drunk by animals, and occasionally also by people }\end{array}$ \\
\hline $\mathrm{Cd}$ & $3 \mu \mathrm{g} \mathrm{dm}{ }^{-3}$ & $\begin{array}{l}6 \text { wells exceed the health-based guidance level. The highest value } \\
\text { (E 19) was } 13.7 \mu \mathrm{g} \mathrm{dm}^{-3}\end{array}$ \\
\hline $\mathrm{Mn}^{*}$ & $400 \mu \mathrm{g} \mathrm{dm}^{-3}$ & $\begin{array}{l}\text { One well exceeds the level (E3): } 572.5 \mu \mathrm{g} \mathrm{dm}^{-3} \text {. The presence of Mn } \\
\left(>0.0 \mu \mathrm{g} \mathrm{dm}^{-3}\right) \text { was observed in } 11 \text { wells }\end{array}$ \\
\hline $\mathrm{Ni}$ & $70 \mu \mathrm{g} \mathrm{dm}{ }^{-3}$ & $\begin{array}{l}2 \text { wells exceed the level (E1): } 76.8 \mu \mathrm{g} \mathrm{dm}^{-3},(\mathrm{E} 8) 93.6 \mu \mathrm{g} \mathrm{dm}^{-3} \text {. The } \\
\text { presence of } \mathrm{Ni}\left(>0.0 \mu \mathrm{g} \mathrm{dm}^{-3}\right) \text { was observed in } 13 \text { wells }\end{array}$ \\
\hline $\mathrm{Na}$ & $200 \mathrm{mg} \mathrm{dm}^{-3}$ & Well no. E4 - maximum value $\left(1396 \mathrm{mg} \mathrm{dm}^{-3}\right)$ \\
\hline $\mathrm{NH}_{3}$ and $\mathrm{NH}_{4}$ & $0.2 \mathrm{mg} \mathrm{dm}^{-3}$ & Well no. E18 - maximum value $\left(3.3 \mathrm{mg} \mathrm{dm}^{-3}\right)$ \\
\hline $\mathrm{Cl}$ & $250 \mathrm{mg} \mathrm{dm}^{-3}$ & All wells \\
\hline $\mathrm{SO}_{4}, \mathrm{CaSO}_{4}$ & $\begin{array}{l}\text { Sodium sulfate } 250 \mathrm{mg} \mathrm{dm}^{-3} \\
\text { Calcium sulfate } 1000 \mathrm{mg} \mathrm{dm}^{-3}\end{array}$ & All wells except E17 \\
\hline $\mathrm{Fe}$ & $0.3 \mathrm{mg} \mathrm{dm}^{-3}$ & All wells except E17 \\
\hline $\mathrm{Cr}$ & $50 \mu \mathrm{g} \mathrm{dm}{ }^{-3}$ & Well no. E9 - maximum value $\left(88.1 \mu \mathrm{g} \mathrm{dm}^{-3}\right)$ \\
\hline Water hardness & $500 \mathrm{mg} \mathrm{dm}^{-3}$ & Well no. E9 - maximum value $\left(925 \mathrm{mg} \mathrm{dm}^{-3}\right)$ \\
\hline
\end{tabular}

*Informal guideline value, delivered by WHO.

The analysed water had an excessive concentration of parameters affecting its heath properties, i.a., $\mathrm{NO}_{3}, \mathrm{Cd}, \mathrm{Mn}, \mathrm{Ni}$. In the dry areas, elevated concentration of sodium and its negative influence on the ecosystem have been pointed out many times (i.a. Bahaj et al. 2013, Bouchaou et al. 2008, El Mandour et al. 2008, Rochdane et al. 2015, Dłużewski et al. 2017, Latos et al. 2018, Szczucińska et al. 2019). The low quality of alluvial water was observed in areas where wells are located in alluvial formations.

\section{Conclusions}

In the dry zone, not only the amount of freshwater is very limited. Its quality is another factor that limits the possible use of the water. The Erfoud oasis, located in hot and dry climate, is an example of an area encountering these two problems. Irrigation suitability of alluvial water in the Erfoud oasis, Morocco is limited. Based on $\mathrm{KR}$ and $\mathrm{MH}$ ratios, the vast majority of the water was classified as unsuitable for irrigation purposes. Although \% $\mathrm{Na}$ indicates that the groundwater is permissible, and on the basis of the permeability index the water is classified as moderate for irrigation purposes, classification using the SAR vs EC diagram confirms the high and very high alkali and salinity hazard. The mean value of EC was $9.5 \mathrm{mS} \mathrm{cm}^{-1}$, with the maximum of
$15.8 \mathrm{mS} \mathrm{cm}^{-1}$. The anthropogenic impact on water quality is clearly visible not only in sodium concentrations because of water intake, but also in the high nitrate contents in the groundwater. Agriculture, wastewater or pollution from septic tanks can significantly increase nitrate content in the groundwater.

The study carried out in Erfoud shows the need to monitor the quality of alluvial waters. The observed excess of sodium destroys the soil structure, and as a result, the soil loses its ability to support vegetation growth. Salinity also leads to decreased permeability of soil, which may make the cultivation of plants impossible. Because alluvial water is extensively used by the local residents, its quality is of primary importance. In the context of water management in dry climates, irregular water supply is a huge problem. Socio-economic development, causing the growth in adaptation ability to cope with the problem of water shortage, is currently a big challenge to the Moroccan economy. It is necessary to limit the overexploitation of water for irrigation purposes, and to introduce the drop watering method of wide-scale. The activities should especially take place in areas where recharge area contains evaporate rocks, mainly halite and gypsum, and salinity exceeds the permitted threshold in groundwater. Results suggest high chemical stress in the groundwater of this area, which should be eliminated to avoid long-term soil and human health issues. 


\section{Acknowledgments}

This research was financed by Ministry of Science and Higher Education from the budgetary funds for science for the years 2016-2019, as a research project within the Diamond Grant programme (grant no. 0035/DIA/2016/45). The authors wish to thank Mr Ismail Belmadani, Mr Jacek Płocieniczak and Dr Łukasz Wejnerowski for their assistance during the field studies and Dr Ahmed Fekri for his helpful comments.

\section{Author`s contribution}

The overall percentage contribution of the individual authors to the article presents as follow: Beata Latos $-40 \%$, Anna Szczucińska - 30\%, Rafał Kozłowski - 30\%.

\section{References}

Akdi M., Sedra M.B., 2015. Prospective Study: Choice of the Potential Sites Intended for the New Renewable Energy Approach. International Journal of Sustainable and Green Energy. Special Issue: Wind-Generated Waves, 2D Integrable $K d V$ Hierarchies and Solitons 4(3-2): 6-9.

Alaya B.M., Saidi S., Zemni T., Zargouni F., 2014. Suitability assessment of deep groundwater for drinking and irrigation use in the Djeffara aquifers (Northern Gabes, south-eastern Tunisia). Environmental Earth Sciences 71(8): 3387-3421.

Alaya M.B., Khouni R., Zemni T., Khmeri S., Zargouni F., 2016. A multicriteria approach to study genesis of salted groundwater, Northern Jeffara (South-eastern Tunisia). Larhyss Journal 28: 103-119.

Ammar B.S., Taupin J.D., Zouari K., Khouatmia M., 2016. Identifying recharge and salinization sources of groundwater in the Oussja Ghar el Melah plain (northeast Tunisia) using geochemical tools and environmental isotopes. Environmental Earth Sciences 75(7): 606.

Andrade A.I.A.S.S, Stigter T.Y., 2009. Multi-methode assessment of nitrate and pesticide contamination in shallow alluvial groundwater as a function of hydrogeological setting and land use. Agricultural Water Management 96: 1751-1765.

Apello C.A.J., Postma D., 1994. Geochemistry, groundwater and pollution. Balkema, Rotterdam, 683.

Arumugam K., Elangovan K., 2009. Hydrochemical characteristics and groundwater quality assessment in Tirupur Region, Coimbatore District, Tamil Nadu, India. Environmental Geology 58: 1509-1520.

Bahaj T., Kacimi I., Hilali M., Kassou N., Mahboub A., 2013. Preliminary study of the groundwater geochemistry in the sub-desert area in Morocco: case of the Ziz-Ghris basins. Procedia Earth and Planetary Science 7: 44-48.

Baran N., Mouvet C., Négrel Ph., 2007. Hydrodynamic and geochemical constraints on pesticide concentrations in the groundwater of an agricultural catchment (Brévilles, France). Environmental Pollution 148: 729-738.

Batista S., Silva E., Galhardo S., Viana P., Cerejeira M.J., 2002. Evaluation of pesticide contamination of ground water in two agricultural areas of Portugal. International Journal of Environmental Analytical Chemistry 82: 601-609.

Bouchaou L., Michelot J.L., Vengosh A., Hsissou Y., Qurtobi M., Gaye C.B., Bullen T.D., Zuppi G.M., 2008. Application of multiple isotopic and geochemical tracers for investigation of recharge, salinization, and residence time of water in the Souss-Massa aquifer, Southwest of Morocco. Journal of Hydrology 352(3-4): 267-287.

Cerejeira M.J., Viana P., Batista S., Pereira T., Silva E., Valério M.J., Silva A., Ferreira M., Silva-Fernandes A.M., 2003. Pesticides in Portuguese surface and ground waters. $W a-$ ter Research 37: 1055-1063.

Charef A., Guedes A., Noronha F., Sousa M., 2009. Fossil and present-day hydrotermal fluids from North Tunisia: an example of a dynamic fluid evolution. Cadernos Laboratorio Xeolóxico de Laxe Coruña 34: 43-58.

Deshpande S.M., Ather K.R., 2012. Evaluation of groundwater quality and its suitability for drinking and agriculture use in parts of Vaijapur, District Aurangabad, MS, India. Research Journal of Chemical Sciences 2(1): 25-31.

Dłużewski M., Kozłowski R., Szczucińska A., 2017. Potential use of alluvial groundwater for irrigation in arid zones - Mhamid Oasis (S Morocco). Ecological Chemistry and Engineering $S$ 24(1): 129-140.

El Bakouri H., Ouassini A., Morillo J., Usero J., 2008.Pesticides in groundwater beneath Loukkos perimeter, Northwest Morocco. Journal of Hydrology 34: 270-278.

EL Khoumsi W., Hammani A., Kuper M., Bouaziz A., 2014. Deterioration of groundwater in arid environments: what impact in oasis dynamics? Case study of Tafilalet, Morocco. International Journal of Environmental, Ecological, Geological and Marine Engineering 8(11): 689-695.

El Mandour A., El Yaouti C.F., Fakir C.Y., Zarhloule C.Y., Benavente C.J., 2008. Evolution of groundwater salinity in the unconfined aquifer of Bou-Areg, Northeastern Mediterranean coast, Morocco. Environmental Geology 54(3): 491-503.

Fakharian K., Narany T.S., 2016. Multidisciplinary approach to evaluate groundwater salinity in Saveh Plain, Iran. Environmental Earth Sciences 75(7): 624.

Fakir Y., Zerouali A., Aboufirassi M., Bouabdelli M., 2001. Exploitation et salinité des aquifères de la Chaouia côtière, littoral atlantique, Maroc Potential exploitation and salinity of aquifers, Chaouia coast, Atlantic shoreline, Morocco. Journal of African Earth Sciences 32(4): 791-801.

Foster S., Garduño H., 2013. Irrigated agriculture and groundwater resources-towards an integrated vision and sustainable relationship. Water Science and Technology 67(6): 1165-1172.

Hamzaoui-Azaza F., Ketata M., Bouhlila R., Gueddari M., Riberio L., 2011. Hydrogeochemical characteristics and assessment of drinking water quality in Zeuss-Koutine aquifer, southeastern Tunisia. Environmental Monitoring and Assessment 174(1-4): 283-298.

Hem J.D., 1985. Study and interpretation of the chemical characteristics of natural water. Department of the Interior, US Geological Survey 2254.

Hildenbrandt A., Guillaom M., Lacorte S., Tauler R., Barcelo D., 2008. Impact of pesticides used in agriculture and vineyards to surface and groundwater quality (North Spain). Water Research 42: 3315-3326.

Jalali M., 2009. Groundwater geochemistry in the Alisadr, Hamadan, Western Iran. Environmental Monitoring and Assessment 166(1-4): 359-369. 
Kelly W. P., 1963. Use of Saline Irrigation. Water. Soil Science, 95(4), 355-391.

Kirchner J.W., Feng X., Neal C., 2001. Catchment-scale advection and dispersion as a mechanism for fractal scaling in stream tracer concentrations. Journal of Hydrology 254(1-4): 82-101.

Lachaal F., Mlayah A., Anane M., Bédir M., Tarhouni J., Leduc C., 2013. Comprehension and hydrogeological conceptualization of aquifer in arid and semi-arid regions using integrated hydrogeological information system: case of the deep aquifer of Zéramdine-Béni Hassen (east-central Tunisia). Arabian Journal of Geosciences 6(7): 2655-2671.

Laftouhi N., Vanclooster M., Jalal M., Witam O., Aboufirassi M., Bahir M., Persoons É., 2003. Groundwater nitrate pollution in the Essaouira Basin (Morocco). Comptes Rendus Geosciences 335: 307-317.

Latos B., Sobczak-Szelc K., Skocki K., Kozłowski R., Szczucińska A., 2018. Chemical composition of utility water in the arid climate zone on the examples of Kébili and Medenine regions (southern Tunisia). Prace Geograficzne 155: 139-156.

Lgourna Z., Warner N., Bouchaou L., Boutaleb S., Hssaisoune M., Tagma T., Ettayfi N., Vengosh A., 2014. Elucidating the sources and mechanisms of groundwater salinization in the Ziz Basin of southeastern Morocco. Environmental Earth Sciences 73(1): 77-93.

Mainguet M., Dumay F., Kabiri L., Rémini B., 2011. Prodromes of desertification in the Oasis of Tafilalet (Morocco) and specific local solutions. In: H.G. Brauch, Ú.O.Spring, Cz.Mesjasz, J. Grin, P. Kameri-Mbote, B. Chourou, P. Dunay, J. Birkmann, (eds.) Coping with Global Environmental Change, Disasters and Security. Hexagon Series on Human and Environmental Security and Peace 5: 901-919.

Morvan X., Mouvet C., Baran N., Gutierrez A., 2006. Pesticides in the groundwater of a spring draining a sandy aquifer: Temporal variability of concentrations and fluxes, Journal of Contaminant Hydrology 87(3-4): 176-190.
Piper A.M., 1944. A graphic procedure in geochemical interpretation of water analyses. Eos, Transactions American Geophysical Union 25(6): 914-928.

Ragunath H. M., 1987. Groundwater, 2nd edn. Wiley Eastern Ltd, New Delhi.

Richards L. A., 1954. Diagnosis and improvement of saline and alkali soils; Agri. Hand book 60, US Dept. of Agriculture, Washington DC, 1954(160).

Rochdane S., Reddy D.V., El Mandour A., 2015. Hydrochemical and isotopic characterisation of Eastern Haouz plain groundwater, Morocco. Environmental Earth Sciences 73: 3487-3500.

Szabolcs I., Darab C., 1964. The influence of irrigation water of high sodium carbonate content of soils. In: Proceedings of $8^{\text {th }}$ international congress of ISSS, transmission 1964(2), 803-812.

Szczucińska A., Dłużewski M., Kozłowski R., Niedzielski P., 2019. Hydrochemical Diversity of a Large Alluvial Aquifer in an Arid Zone (Draa River, S Morocco). Ecological Chemistry and Engineering S 26(1): 81-100.

Warner N., Lgourna Z., Bouchaou L., Boutaleb S., Tagma T., Hsaissoune M., Vengosh A., 2013. Integration of geochemical and isotopic tracers for elucidating water sources and salinization of shallow aquifers in the sub-Saharan Drâa Basin, Morocco. Applied Geochemistry 34: 140-151.

Whitehead P., Wilby R., Battarbee R., Kernan M., Wade A., 2009. A review of the potential impacts of climate change on surface water quality. Hydrological Sciences Journal 54(1): 101-123.

Wilcox L.V., 1955. Classification and Use of Irrigation Water. US Department of Agriculture, New York. Online: www. ars.usda.gov/arsuserfiles/20360500/pdf_pubs /P0192. pdf (accessed 13 February 2019).

Williams W.D., 2001. Anthropogenic salinisation of inland waters. Hydrobiologia 466(1-3): 329-337.

WHO [World Health Organization], 2017. Guidelines for drinking-water quality: first addendum to the fourth edition, 1st add, 4th ed. Online: apps.who.int/iris/handle/10665/254636 (accessed 14 May 2018). 